Lingua Rima: Jurnal Pendidikan Program Studi Bahasa dan Sastra Indonesia

Vol. 9 No. 1 Juli 2020

\title{
PENGARUH METODE SOSIODRAMA TERHADAP KETERAMPILAN BERBICARA SISWA KELAS V SDN SERPONG 1 KOTA TANGERANG SELATAN
}

\author{
Dian Apriyanti ${ }^{1}$, Hamdah Siti Hamsanah Fitriani ${ }^{2}$, Candra Puspita Rini ${ }^{3}$ \\ Universitas Muhammadiyah Tangerang \\ Dianapriyanti1996@gmail.com ${ }^{1}$ \\ vitrianivit@gmail.com² \\ candrapuspitarini@gmail.com ${ }^{3}$
}

\begin{abstract}
ABSTRAK
Penelitian ini bertujuan untuk mengetahui pengaruh metode sosiodrama terhadap keterampilan berbicara siswa kelas V SD Negeri Serpong 1 Kota Tangerang Selatan. Metode yang digunakan pada penelitian ini adalah metode penelitian kuantitatif jenis Quasi Eksperimen dengan desain penelitiannya Nonequivalent Control Group Design. Populasi dalam penelitian ini adalah siswa kelas V SD Serpong 1 Kota Tangerang Selatan. Pengumpulan data dilakukan melalui tes perbuatan (performancetest). Teknik analisis data yang digunakan adalah t-test (Pretes - Postest) uji beda dua mean data tidak berpasangan independent dengan menggunakan taraf signifikasi $\alpha=0,05$. Pengujian hipotesis menggunakan statistik inferensial yang diawali uji normalitas, uji homogenitas, dan uji-t The Pooled Variance Model. Berdasarkan hasil penelitian menunjukan, bahwa dengan menggunakan metode pembelajaran sosiodrama pada keterampilan berbicara siswa, dengan materi drama dapat meningkatkan prestasi belajar siswa yang lebih baik. Hal ini dapat dilihat dari uji-t pretes diperoleh bahwa $t_{\text {hitung }}=0,501$ dan $t_{\text {tabel }}=2,0021$ pada taraf signifikasi 5\% $(\alpha=0,05)$ dengan ini pretes yang diperoleh tidak terdapat perbedaan keterampilan berbicara antara kelas kontrol dan kelas eksperimen. Berdasarkan hasil perhitungan uji-t postes diperoleh $t_{\text {hitung }}=4,155>t_{\text {tabel }}=2,0021$. Maka dapat disimpulkan $\mathrm{H}_{0}$ ditolak $\mathrm{H}_{1}$ diterima.Dengan ini dapat dinyatakan terdapat perbedaan keterampilan berbicara antara siswa yang diberi metode pembelajaran sosiodrama dengan siswa yang diberi metode konvensional di kelas V SD Negeri Serpong 1 Kota Tangerang Selatan.
\end{abstract}

Kata Kunci: Metode Sosiodrama, Keterampilan Berbicara

\section{A. PENDAhuluan}

Keterampilan berbicara sangat diperlukan oleh seorang siswa untuk kelancaran proses pembelajaran. Siswa yang memiliki kecakapan berbicara cenderung dapat menerima pembelajaran dengan baik dan dapat memberikan umpan balik dalam pembelajaran. Keterampilan berbicara ini seharusnya dapat dimiliki oleh siswa pada semua jenjang pendidikan, tidak terkecuali pada siswa Sekolah Dasar (SD). Kemampuan berbicara siswa SD cenderung 
Lingua Rima: Jurnal Pendidikan Program Studi Bahasa dan Sastra Indonesia

Vol. 9 No. 1 Juli 2020

masih kurang, karena keterampilan berbicara siswa SD belum terasah secara maksimal. Guru cenderung masih menggunakan metode tradisional yaitu ceramah yang berdampak pada kepasifan siswa.

Hasil observasi di SD Negeri Serpong 1 Kota Tangerang Selatan terkait dalam permasalahan keterampilan berbicara siswa yang masih rendah. Hal ini disebabkan pembelajaran masih berpusat pada guru yang belum menggunakan metode pembelajaran aktif dan kreatif. Aktivitas siswa dalam pembelajaran menjadi pasif dan kepercayaan diri siswa dalam berinteraksi sangat kurang. Para siswa jarang sekali bertanya maupun memberikan umpan balik karena siswa kurang percaya diri dan takut dalam mengungkapkan ide dan pemikirannya.

Upaya mengatasi permasalahan tersebut, peneliti memilih metode sosiodrama.Dengan metode sosiodrama untuk meningkatkan kemampuan siswa dalam berbicara. Teknik sosiodrama adalah suatu jenis teknik simulasi yang umumnya digunakan untuk pendidikan sosial dan hubungan antar siswa. Pada metode ini, proses pembelajaran terpusat siswa dalam memperoleh dan mengaplikasikan pengetahuan baru. Siswa dapat mengeksplorasi pengetahuan dalam bentuk aplikasi keterampilan berbicara. Penelitian ini dilakukan dengan harapan akan menjadi bahan masukan yang berarti bagi pembelajaran drama yang menyenangkan dan membuat siswa menjadi berani untuk dapat berbicara di hadapan teman-temannya mau pun dihadapan umum.

\section{B. KAJIAN TEORI}

Keterampilan berbicara adalah proses berkomunikasi dengan mengucapkan bunyi-bunyi artikulasi untuk menyampaikan maksud sehingga maksud tersebut dapat dipahami oleh orang lain. Proses berkomunikasi agar mudah dipahami maka kata yang diucapkan tentunya harus jelas dan lancar. Berbicara mempunyai tujuan tertentu yang dapat berkomunikasi dengan baik dengan orang lain. Pendapat ini sesuai dengan apa yang dikemukakan oleh Tarigan (2015:16), berbicara adalah berkomunikasi yang penyampaiannya dilakukan secara efektif. Maka, pembicara harus memahami makna segala sesuatu yang ingin dikomunikasikan. Pembicara harus mampu mengevaluasi efek komunikasinya terhadap pendengarnya. Selain itu, harus mengetahui prinsipprinsip yang mendasari segala situasi pembicaraan, baik secara umum maupun perorangan. Berbicara mempunyai tiga maksud umum, yaitu: (1) memberitahukan dan melaporkan (to inform); (2) menjamu dan menghibur (to entertain); (3) membujuk, mengajak, mendesak, dan meyakinkan (to persuade). 
Lingua Rima: Jurnal Pendidikan Program Studi Bahasa dan Sastra Indonesia

Vol. 9 No. 1 Juli 2020

Menurut Saddhono (2005:55) berpendapat bahwa "Berbicara adalah salah satu alat komunikasi penting untuk dapat menyatakan diri sebagai anggota masyarakat. Dengan kata lain, untuk menghubungkan sesama anggota masyarakat diperlukan komunikasi”. Selain itu, menurut Mulyati (2010:128) berpendapat bahwa "Berbicara adalah aktivitas menyampaikan pesan-pesan dalam berkomunikasi dengan menggunakan bunyi-bunyi yang dihasilkan oleh alat ucap manusia (kegiatan produktif ragam lisan)". Adanya berbicara memudahkan kita untuk mendapatkan suatu informasi dari orang lain yang sangat penting dan bermanfaat. Tentunya jika kita tidak mudah untuk berkomunikasi dengan orang lain maka akan membuat kita menjadi tidak mengerti dan tidak tahu tentang apa yang sedang dibicarakan.

Keterampilan berbicara, dapat dilakukan melalui metode sosiodrama. Menurut Sagala (2013:213) berpendapat bahwa "Metode sosiodrama berarti cara menyajikan bahan pelajaran dengan mempertunjukkan atau mempertontonkan atau mendramatisasikan cara tingkah laku dalam hubungan sosial" Siswa dapat belajar dan merasakan bagaimana cara memainkan peran yang memang belum pernah ia rasakan sebelumnya, dengan karakter peran yang dimainkannya berbeda, tentunya akan menjadi sebuah pengalaman dalam hidupnya.

Roestiyah (2008) berpendapat bahwa "Metode sosiodrama ialah siswa dapat mendramatisasikan tingkah laku, atau ungkapan gerak-gerik wajah seseorang dalam hubungan sosial atau antar manusia" (h.90). Dengan siswa mencoba metode sosiodrama ini akan membuat siswa pintar dalam memainkan perannya, dengan belajar memainkan peran, maka siswa mempunyai keterampilan atau bakat dalam bermain sinetron. Metode sosiodrama ini dilakukan untuk membuat siswa menjadi lebih berani dalam berbicara dihadapan teman-temannya maupun dihadapan umum.Terutama pada siswa yang memang mempunyai sikap yang sangat pemalu dan tidak berani untuk berbicara, tentunya dengan siswa mencoba metode sosiodrama ini dapat mengubah pribadi dirinya menjadi lebih berani dan percaya diri dalam berbicara.

\section{METODE PENELITIAN}

Metode penelitian yang digunakan adalah metode penelitian Quasi Eksperimen dengan desain penelitian yaitu Nonequivalent Control Group Design. Penelitian ini dilakukan di SD Negeri Serpong 1 Kota Tangerang Selatan. Penelitian ini dilakukan menggunakan dua kelas yaitu kelas eksperimen dan kelas kontrol. Kelas eksperimen adalah kelas yang diberi perlakuan yaitu berupa penerapan metode sosiodrama yaitu kelas VA, sedangkan kelas kontrol merupakan kelas yang tidak diberi perlakuan (metode konvensional) yaitu kelas VB. Penelitian ini 
Lingua Rima: Jurnal Pendidikan Program Studi Bahasa dan Sastra Indonesia

Vol. 9 No. 1 Juli 2020

menggunakan teknik pengumpulan data berupa tes perbuatan praktik (performance test). Teknik analisis data yang dipakai adalah statistika deskriptif dan statistik inferesnsial (parametrik).

\section{HASIL PENELITIAN DAN PEMBAHASAN}

Berdasarkan hasil perhitungan penelitian data pretes dari kelas eksperimen dan kelas kontrol dengan menggunakan uji-t menunjukkan bahwa kemampuan awal siswa ke dua kelas tersebut dalam keterampilan berbicara pada materi drama tidak berbeda secara signifikan pada taraf signifikansi 5\% $(\propto=0,05)$. Dari hasil analisis diperoleh rata-rata nilai pretes kelas eksperimen dan kelas kontrol yaitu 53,3 untuk nilai pretes kelas eksperimen dan 52,5 untuk nilai pretes kelas kontrol yang memiliki jumlah rata-rata tidak jauh berbeda, standar deviasi pretes kelas eksperimen $(6,74)^{2}=45,42$ dan standar deviasi pretes pada kelas kontrol $(6,28)^{2}=39,43$ $\mathrm{t}_{\text {hitung }}=0,501<\mathrm{t}_{\text {tabel }}=2,0021$ maka dapat disimpulkan $\mathrm{H}_{1}$ ditolak $\mathrm{H}_{0}$ diterima, artinya tidak terdapat perbedaan keterampilan berbicara antara kelas kontrol dan kelas eksperimen. Hal ini disebabkan karena belum ada proses penerapan metode sosiodrama atau perlakuan di dalam kelas.

Setelah diberikan perlakuan dalam kegiatan pembelajaran yaitu pada kelas eksperimen dengan metode sosiodrama dan kelas kontrol dengan metode konvensional.Sehingga diperoleh data postes atau tes akhir dengan menggunakan uji t, memberikan hasil bahwa siswa yang diberikan metode sosiodrama lebih mengalami peningkatan dibandingkan dengan siswa yang diberikan metode konvensional.Hal ini dapat dilihat dari hasil analisis yang diperoleh rata-rata postes kelas eksperimen 72,33 , rata-rata kelas kontrol 64,8, standar deviasi postes kelas eksperimen $(7,53)^{2}=56,70$ dan standar deviasi postes kontrol $(7,27)^{2}=52,85$ maka telah dilakukan uji hipotesis yang menunjukan hasil $t_{\text {hitung }}=4,155>t_{\text {tabel }}=2,0021$ maka dapat disimpulkan $\mathrm{H}_{0}$ ditolak $\mathrm{H}_{1}$ diterima, artinya terdapat perbedaan keterampilan berbicara antara siswa yang diberi metode pembelajaran sosiodrama dengan siswa yang diberi metode konvensional.

Selama proses pembelajaran berlangsung di kelas kontrol, peneliti menyampaikan materi pembelajaran dari awal sampai akhir. Siswa hanya mendengarkan yang disampaikan oleh peneliti. Ketika peneliti memberikan tugas pada setiap siswa untuk mempraktikan keterampilan berbicara dengan memainkan drama tanpa diberi metode pembelajaran sosiodrama, memainkan drama yang terdiri dari 4 siswa dari setiap kelompok, dan siswa hanya melakukan praktik 
Lingua Rima: Jurnal Pendidikan Program Studi Bahasa dan Sastra Indonesia

Vol. 9 No. 1 Juli 2020

semampu mereka tanpa ada rangsangan yang diberikan oleh peneliti. Proses pemebelajaran yang demikian mengakibatkan keterampilan berbicara siswa kurang terangsang dan tidak dapat dikembangkan dengan baik.

Pada kelas eksperimen pembelajaran dimulai dengan peneliti bertanya mengenai drama (acting) kepada siswa dengan menunjukan ekspresi wajah, kemudian siswa diberikan rangsangan terlebih dahulu dengan mengamati peneliti memainkan drama. peneliti menunjukan teknik berbicara dalam sosiodrama yaitu kelantangan, tingkat rasa percaya diri (keberanian), intonasi, dan artikulasi. Peneliti didampingi oleh beberapa siswa sebagai percontohan, karena peneliti tidak dapat memperlihatkan video dan di sekolah yang dijadikan penelitian pun tidak menyediakan infokus. Peneliti meminta siswa sebagai contoh untuk mencoba mempraktikannya terlebih dahulu, sebelum peneliti membuat kelompok untuk siswa yang akan memainkan drama. Siswa di kelas eksperimen ini memainkan drama dengan menggunakan metode pembelajaran sosiodrama, yang terdiri dari 4 siswa dari setiap kelompok. Siswa melakukan praktik atau memainkan drama semampu mereka, dan mereka pun memainkannya dengan sangat baik dibandingkan dengan siswa di kelas kontrol.

Berdasarkan hasil yang telah diperoleh, pada kelas eksperimen ini siswa sangat antusias dalam pembelajaran. Setiap siswa mencoba maju kedepan kelas untuk menjelaskan kembali cerita yang terdapat di dalam naskah dialog drama yang sudah dimainkan sehingga siswa lebih berani. Namun, di kelas kontrol yang beberapa siswanya kurang berani untuk mencoba maju ke depan kelas. Mereka kurang berani untuk menjelaskan kembali cerita yang terdapat di dalam naskah dialog drama yang sudah dimainkannya. Pada kelas eksperimen ini siswa menjelaskan kembali cerita yang terdapat di dalam naskah drama tanpa harus ditunjuk oleh peneliti, dan siswa berani serta dapat mengungkapkan pendapat mereka tentang cerita yang terdapat di dalam naskah drama dengan sangat baik. Kelas eksperimen lebih aktif jika dibandingkan dengan kelas kontrol yang masih kurang aktif. Maka hasil penelitian ini menunjukan bahwa terdapat perbedaan keterampilan berbicara antara siswa yang diberi metode pembelajaran sosiodrama dengan siswa yang diberi metode konvensional di kelas V SD Negeri Serpong 1. Hal ini berarti bahwa metode sosiodrama sangat berpengaruh terhadap keterampilan berbicara siswa kelas $\mathrm{V}$ SD Negeri Serpong 1.

\section{E. SIMPULAN}


Simpulan dari hasil penelitian ini menunjukan bahwa terdapat perbedaan keterampilan berbicara antara siswa yang diberi metode pembelajaran sosiodrama dengan siswa yang diberi metode konvensional di kelas V SD Negeri Serpong 1 Kota Tangerang Selatan. Hal ini terbukti dari hasil perhitungan homogenitas postes kelas eksperimen dan kelas kontrol uji $\mathrm{F}_{\text {hitung }}=1,07<$ $\mathrm{F}$ tabel 1,85 , dengan demikian dapat disimpulkan bahwa data sampel dari kelas eksperimen dan kelas kontrol homogen, sedangkan dari perhitungan Uji-t pada hasil postes kelas eksperimen dan kelas kontrol diperoleh nilai $t_{\text {hitung }}=4,115>t_{\text {tabel }}=2,0021$ maka dapat disimpulkan $\mathrm{H}_{0}$ ditolak $\mathrm{H}_{1}$ diterima, artinya terdapat perbedaan keterampilan berbicara antara siswa yang diberi metode pembelajaran sosiodrama dengan siswa yang diberi metode konvensionl, pada siswa kelas V SD Negeri Serpong 1 Kota Tangerang Selatan. Dan ternyata metode sosiodrama ini sangat efektif dan baik untuk digunakan dalam meningkatkan hasil belajar siswa. Hal ini dapat dilihat dari ratarata mean yang diperoleh kelas eksperimen lebih besar dibandingkan dengan rata-rata mean yang diperoleh kelas kontrol yaitu 72,33> 64,80.

\section{F. DAFTAR PUSTAKA}

Mulyati, Y., dkk. 2010. Keterampilan Berbahasa Indonesia SD. Jakarta: Universitas Terbuka. Roestiyah. 2008. Strategi Belajar Mengajar. Jakarta: Rineka Cipta.

Saddhono, K \& Slamet.2005.Pembelajaran Keterampilan Berbahasa Indonesia. Bandung: Graha Ilmu.

Sagala, S. 2013. Konsep dan Makna Pembelajaran. Bandung: Alfabeta.

Tarigan, H. G. 2015. Berbicara: Sebagai Suatu Keterampilan Berbahasa. Bandung: Angkasa. 